\title{
САМООСВІТА ЯК УМОВА ФОРМУВАННЯ ПРОФЕСІЙНОЇ КОМПЕТЕНТНОСТІ МАЙБУТНЬГО ВЧИТЕЛЯ ТЕХНОЛОГІЙ
}

\begin{abstract}
Хріненко Т.В. Самоосвіта як умова формування професійної компетентності майбутньго вчителя технологій.

У статті визначено сутність самоосвітньої діяльності вчителя технологій у формуванні професійної компетентності, проаналізовано зміст поняття «самоосвіта вчителя технологій».

Ключові слова: компетентність, самоосвіта, самоосвітня діяльність, вчитель технології.

Хриненко Т.В. Самообразование как условие формирования профессиональной компетентности будущего учителя технологий.

В статье раскрывается значение самообразования учителя технологий в формировании профессиональной компетентности, проанализировано содержание понятия «самообразование учителя технологий».

Ключові слова: компетентность, самообразование, самообразовательная деятельность, учитель технологии.

Hrinenko T. Self-education as a condition for the formation of professional competence of future teachers of technology.

In the article the value of self-education activity of teacher of technologies is certain in forming of professional competence, maintenance of concept "self-education of teacher of technologies" is analysed.

Key words: competence, self-education, self-education activity, teacher of technology.
\end{abstract}

Традиційний підхід до підготовки вчителя технологій не враховує гострої необхідності у формуванні кожним вчителем су'єктно-особистісного досвіду самопроектування, самоорганізації і самореалізації власної траєкторії саморозвитку. Відсутність такого досвіду негативно позначається на якості розв'язання професійних задач. Для цього потрібно постійно поповнювати свої знання, жити актуальними проблемами сучасної науки, іiі досягненнями, вивчати передовий досвід, швидко підхоплювати творчі ідеї інших та використовувати їх для поліпшення своєї діяльності.

Компетентність фахівця в галузі освіти об'єктивно набуває все більшої актуальності завдяки ускладненню і постійному розширенню соціального досвіду, сфери освітніх послуг, появі інноваційних типів шкіл, авторських педагогічних програм, проектів, технологій, виникненню різних форм презентації і переробки інформації, зростаючому рівню запитів соціуму.

Категорія «професійна компетентність» визначається головним чином рівнем професійної освіти, досвідом та індивідуальними здібностями людини, ii мотивованими прагненнями до безперервної самоосвіти та самовдосконалення, творчим і відповідальним ставленням до справи [4, с. 74].

Різні аспекти проблеми формування професійної компетентності фахівців досліджували такі вчені: Н. Кузьміна, Дж. Куллахан, О. Пометун, Н. Тализіна, Р. Уайт (становлення та тлумачення поняття компетентності); В. Адольф, Є. Барбіна, Н. Бордовська, Т. Браже, О. Дубасенюк, М. Вачевський, 
А. Вербицький, І. Гушлевська, І. Зязюн, М. Кабардов, Н. Коломінський, С. Кубицький, А. Маркова, Н. Ничкало, Л. Петухова, С. Шишов (проблеми формування професійної компетентності фахівця).

Компетентний фахівець є також індивідуальністю, яка усвідомлює i рефлексує власні цінності, зіставляє, оцінює себе, проектує своє майбутнє. Тому знання, уміння та навички, засоби діяльності $\epsilon$ матеріалом для формування особистості, причому знання визначаються не тільки як певний обсяг інформації, а як уявлення про світ, що накладається на власний соціокультурний, духовний досвід індивіда [5, с.55]. Такий фахівець виходить за рамки предметної галузі своєї професії, він має мати певний творчий потенціал саморозвитку.

Відчуваючи потребу в здобутті знань і обираючи той чи інший шлях іiі задоволення, людина звертається до самоосвіти.

Прогнозування розвитку професійної компетентності вчителя технологій може спрямовуватися за допомогою освітнього самовизначення (прийняття себе як об’єкта безперервної професійної освіти) і професійноособистісного саморозвитку засобами освітньої діяльності [6, с.14].

Метою статті є обгрунтування необхідності організації самоосвітньої діяльності викладача технологій задля формування його професійної компетентності.

Самоосвіта посідає особливе місце в системі формування управлінської компетентності директора школи. На думку В. Чайки, самоосвіта це специфічний вид діяльності, яку особистість здійснює задля задоволення пізнавальних потреб чи покрашення своїх особистісних якостей або здібностей [8, с.235].

Аналіз проблеми самоосвіти у педагогічній теорії здійснено П. Підкасистим, І. Зязюном. Окремі аспекти самоосвіти як форми підвищення кваліфікації розглядалися в працях М. Солдатенка, В. Лутанського, Н. Пшебильського, Т. Симонової, І. Чеснокової та інших; систему безперервної освіти педагогічних працівників досліджували О. Галаган, Б. Гершунський, І. Жерносек, М. Маслов.

Сутнісними характеристиками безперервної освіти вчителя технологій є гнучкість, доступність у часі й просторі. Проблеми самоосвіти у педагогічній теорії здійснено П. Підкасистим [7, с. 26]. Характеризуючи самоосвіту, він на перший план висуває наявність потреби у конкретних знаннях і розвитком природної потреби пізнання, яка проходить декілька фаз у своєму розвитку: виникнення потреби, ії насичення і задоволення. «Це, на його думку, - і складає серцевину самоосвіти як педагогічної проблеми у межах шкільної педагогіки».

Інший бік сутності самоосвіти П. Підкасистий убачає в озброєнні особистості уміннями і навичками організації власної розумової праці, спрямованої здобуття нових знань, пізнання реальних предметів і явищ навколишнього світу.

Для самоосвіти є характерним [3]: 
- здобуття знань як додаткова до основного заняття пізнавальна діяльність, яка пов'язана й взаємообумовлена ним;

- оволодіння знаннями за власною ініціативою стосовно змісту, обсягу, джерел, форм, тривалості та часу проведення занять, незалежного від якого-небудь навчального закладу, засобом з використанням певних програм, консультацій та інших видів керівництва й допомоги відповідних фахівців;

- вирішальне місце в оволодінні знаннями займає індивідуальна самостійна пізнавальна діяльність, хоча не виключаються і колективні форми.

Самоосвіта вчителя технологій - найважливіше завдання, робота над яким дозволяс йому впровадити в дію весь свій творчий потенціал, максимально повно використовувати свої можливості й здібності. Організація самоосвітньої діяльності директора школи є ефективним засобом активізації його творчої самостійності. Самостійність і активність тісно пов'язані так як самостійність - $є$ вища форма активності, що визначається в характері і способах діяльності.

Л. Васильченко пропонує розглядати самоосвіту фахівця як вищу форму вияву пізнавальної активності, для якої характерним є оволодіння знаннями переважно шляхом самостійної пізнавальної діяльності, яка організується за особистою ініціативою людини додатково до ії̈ основного заняття [1, с.12].

Пізнавальна активність вчителя технологій відбиває його ставлення до науки та інноваційного досвіду як джерела продуктивних ідей щодо вдосконалення i розвитку педагогічної практики, до професіоналізму, майстерності, до професійного і загальнокультурного значення компетентності, до різних форм ії підвищення.

Основні компоненти самоосвітньої діяльності можна об'єднати в групи:

- мотиви формування безперервної освіти;

- навички самостійного оволодіння знаннями;

- уміння самоорганізації пізнавальної діяльності;

- уміння розумової діяльності;

- стартовий інтелектуальний потенціал.

Досконала організація самоосвіти залежить від багатьох чинників. Багато залежить від мотивів самоосвіти. Під мотивацією розуміють сукупність внутрішніх та зовнішніх сил, які збуджують фахівця до діяльності та надають їй певного смислу. Мотивація саморозвитку обумовлена професійними освітніми потребами - бажанням удосконалити педагогічну діяльність або уникнути зайвих проблем, для того щоб стати більш професійним.

Визначають три групи мотивів самоосвіти [2, с. 19]. До першої групи було віднесено соціальні мотиви. Другу групу мотивів пов'язала 3 спонукальними силами пізнавального інтересу.

Наступним компонентом самоосвітньої діяльності ми розглядаємо сформованість навичок самостійного оволодіння знаннями - це навички, набуті вчителем на підставі власних психофізіологічних особливостей та удосконалені у процесі життєдіяльності.

Не менш важливим є сформованість уміння розумової діяльності, яке передбачає: чуттєве пізнання; техніка мислення; вибір проблем та шляхів рішення. 
Згідно 3 проведеним дослідженням основними умовами ефективної самоосвітньої вчителя технологій $є$ :

1) визначення напрямку самоосвітньої діяльності;

2) складання індивідуального плану самоосвіти;

3) впровадження його у життя.

Всі напрями самоосвітньої діяльності вчителя технологій можна об'єднати в групи: професійні; гуманітарні; методичні; психологопедагогічні; психологічні; особистісні.

При цьому особливу увагу необхідно звернути на такі питання:

- що вивчається, чи відповідає опрацьована література практичним потребам вчителя технологій;

- актуальність матеріалу в світлі розвитку педагогічної науки;

- систематичність і глибина самоосвітньої роботи;

- застосування в практичній діяльності здобутих знань.

Вчителям технологій було запропоновано визначити чинники, які стоять на заваді їх самоосвітньої діяльності. Відповідно до отриманих відповідей:

$47 \%$ респондентів визначили головною причиною особисту інертність;

$28 \%$ - недостатність ресурсів,

$35 \%$ - недостатність часу та специфіка професійної діяльності.

Головною цінністю самоосвіти стає розвиток у людини здатності до самореалізації творчого потенціалу, спрямованості на саморозвиток протягом усього життя. Тому система самоосвіти вчителя технологій має створюватися з урахуванням сучасних вимог і уявлень про освітню діяльність.

Процес самоосвіти є оптимальним шляхом формування професійної компетентності вчителя технологій. Найважливішим завданням самоосвіти вчителя технологій повинно стати засвоєння фахових знань і поглиблення професійної компетентності. Можна зробити висновок, що його самоосвіта посідає особливе місце в системі формування професійної компетентності директора школи.

\section{Література}

1. Васильченко Л. В. Професійна компетентність керівника школи / Л. Василенко, І. Гришина. - Х. : «Основа», 2006. -208 с.

2. Вербицкий А.А. Активное обучение в высшей школе: контекстный подход / А.А. Вербицкий. - М. : Высш. шк, 1991. - 207 с.

3. Волобуєва Т. Б. Самоосвітня діяльність керівника / Т.Б.Волобуева. - Х. : Основа, 2005. -315 c.

4. Гелбутівська Т. Алгоритм розвитку життєвої компетенції : круглий стіл / T. Гелбутівська // Директор школи, ліцею, гімназії. - 2003 - № 3. - С.5.

5. Локшин В. Професійна компетентність фахівців з управління в соціальній сфері як технології модернізації вищої освіти / В. Локшин // Рідна школа. - 2006. - № 4. - С.54-56.

6. Маркова А. К. Психологический анализ профессиональной компетентности учителя / А. К. Маркова // Сов. педагогика. - 1990. - № 8. - С. 82-88.

7. Пидкасистый П. И. Самостоятельная познавательная деятельность школьников в обучении: теоретико-экспериментальное исследование / И. П. Пидкасистый. - М. : Педагогика, 1980. - 240c.

8. Чайка В. М. Основи дидактики: [навч. посіб. ] / В. М. Чайка. - К. : Академвидав, 2011. $-240 \mathrm{c}$.

Стаття надійшла до редакції 28.05.2012 p. 